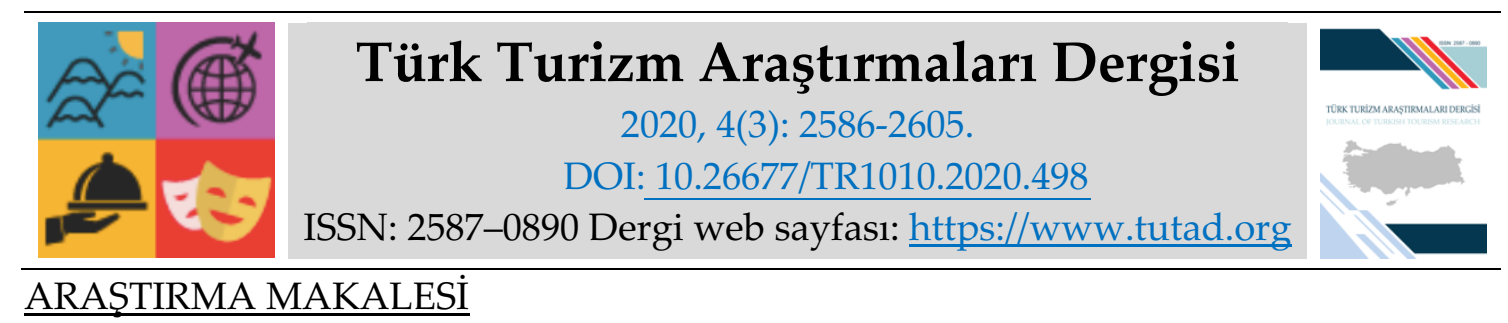

\title{
Kadın Yöneticilerin Sürdürülebilir Kalkınmadaki Rolü: İstanbul'daki Beş Yıldızlı Otel İşletmeleri Örneği
}

Dr. Öğr. Üyesi Gül YILMAZ, İstanbul Arel Üniversitesi, İktisadi ve İdari Bilimler Fakültesi, İstanbul, e-posta: gulyilmaz@arel.edu.tr

ORCID: https://orcid.org/0000-0002-1882-867X

Öz

Bu çalışmanın amacı, kadın yöneticilerin sürdürülebilir kalkınmadaki rolünü turizm sektörü örneği kapsamında ele almaktır. Bu amaç çerçevesinde İstanbul'da beş yıldızlı otel işletmelerinde çalışan kadın yöneticilerin karşılaştıkları güçlüklere yer verilmektedir. Araştırmada, otel işletmelerinde çalışan kadın yöneticilerin yaşadıkları sıkıntıları belirlemek için veri toplama nitel araştırma tekniklerinden yarı yapılandırılmış mülakat tekniği kullanılmaktadır. Beş yıldızlı 10 otelde yönetici pozisyonunda çalışan $10 \mathrm{kadın}$ yönetici ile yüz yüze görüşme tekniği gerçekleştirilmiştir. Mülakat soruları 7 adet olup kadın yöneticilerin yaşadıkları sorunlara değinilmektedir. Yarı yapılandırılmış mülakat tekniği ile toplanan veriler MAXQDA 2018 programı ile analiz edilmiştir. Birleşmiş Milletler UNDP 2030 Sürdürülebilir Kalkınma Amaçlarında belirtildiği gibi kadınlara karşı her türlü ayrımcllığın ortadan kaldırılması için bulgularda; iyileştirme yöntemlerine yer verilmektedir ve analiz yapılmaktadır. Kadın ve kız çocuklarının güçlendirilmesinin, çarpan etkisi yaratma ve ekonomik büyüme ve her alanda gerçekleştirilen gelişmeyi hızlandırıcı bir rolü bulunmaktadır. UNDP, diğer BM ortakları ve uluslararası toplumun da desteğiyle, toplumsal cinsiyet eşitliğini çalışmalarının merkezine almıştır. Özellikle 2000 yılından bu yana yapılan çalışmalar sonunda, 20 yıl öncesine göre çok daha fazla kız çocuğu eğitim alabilmektedir. Çalışmada hizmet sektörü içerisinde yer alan turizm işletmelerinde çalışan kadın yöneticilerin üniversitelerin Turizm ve Otel İşletmeciliği ön lisans ve lisans mezunu olduğu ve çoğunluğunun iş deneyiminin 13-30 yıl arasında olduğu tespit edilmiştir. Ayrıca iş yaşamlarında karşılaştıkları olumlu veya olumsuz durumların neler olduğu aktarılmaktadır. Bu bağlamda, sürdürülebilir kalkınmada kadın yöneticilerin rollerini arttırmak ve kadın erkek hakları eşitliğini vurgulamak amacıyla yerel yönetimlerin, eğitim kurumlarının ve medyanın destekleri ile toplumun bilinçlendirilmesine ihtiyaç bulunmaktadır.

Anahtar Kelimeler: Beş Yıldızlı Otel İşletmeleri, Kadın Yöneticiler, Sürdürülebilir Turizm.

Makale Gönderme Tarihi: 21.04.2020

Makale Kabul Tarihi: 05.07.2020

\section{Önerilen Atıf:}

Yılmaz, G. (2020). Kadın Yöneticilerin Sürdürülebilir Kalkınmadaki Rolü: İstanbul'daki Beş Yıldızlı Otel İşletmeleri Örneği, Türk Turizm Araştırmaları Dergisi, 4(3): 2586-2605.

(c) 2020 Türk Turizm Araştırmaları Dergisi. 


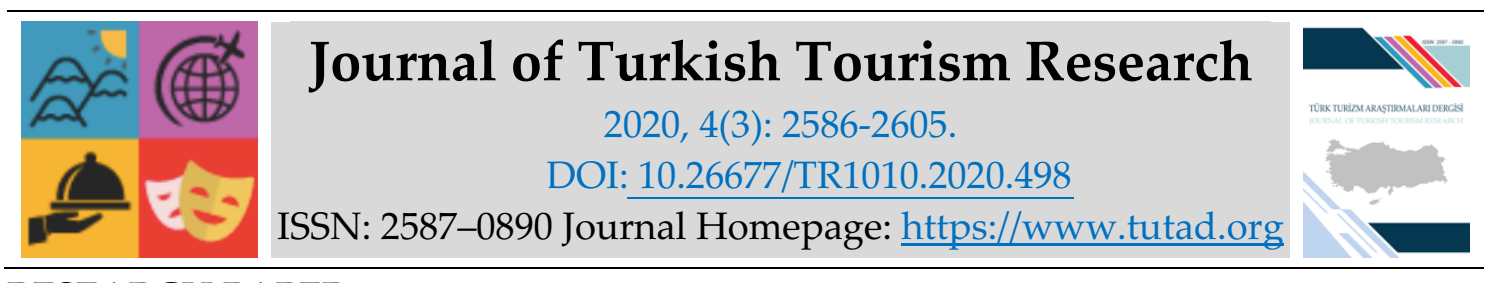

RESEARCH PAPER

\title{
Sustainable Development Role of Women Executives: Example of Five Star Hotel Managements in İstanbul
}

Assistant Prof. Dr. Gül YILMAZ, İstanbul Arel University, Faculty of Economics and Administrative Sciences, İstanbul, e-mail: gulyilmaz@arel.edu.tr

ORCID: https://orcid.org/0000-0002-1882-867X

\begin{abstract}
The purpose of this study is to examine the role of executive women in the development of tourism sector. Here, the aim is to address the challenges faced by women executives working in five-star enterprises in İstanbul. In this research, semi-structured interview, which is one of the qualitative research techniques data collection, is used to identify the problems experienced by the women executives working in hotel businesses. A face-to-face interview technique was held with 10 women executives working in executive positions in 10 five-star hotels. The problems faced by 7 of them are also discussed. Data collected by semi-structured interview technique were analyzed with MAXQDA 2018 program. As stated in the UNDP 2030 Sustainable Development Goals, with the findings to eliminate all kinds of discrimination against women; improvement methods are included and analyzed. Empowering women and girls have a role in accelerating growth and economic growth and development in all areas. UNDP, with the support of other UN partners and the international community, has put gender equality, at the center of its work. Especially, at the end of the studies conducted since 2000, more girls can receive education than 20 years ago. In this study, it has been determined that women executives working in tourism businesses in the service sector are undergraduate and undergraduate graduates of universities, Tourism and Hotel Management, and the majority of their work experience is between 13-30 years. Also, what are the positive or negative situations they encounter in their business lives are explained. In this context, in order to increase the roles of women managers in sustainable development and to emphasize the equality of women and men rights, there is a need to raise awareness of the society with the support of local governments, educational institutions and the media.
\end{abstract}

Keywords: Sustainable Tourism, Five Star Hotel Enterprises, Women Executives.

Received: 21.04 .2020

Accepted: 05.07.2020

\section{Suggested Citation:}

Yılmaz, G. (2020). Sustainable Development Role of Women Executives: Example of Five Star Hotel Managements in İstanbul, Journal of Turkish Tourism Research, 4(3): 2586-2605.

(C) 2020 Türk Turizm Araştırmaları Dergisi. 


\section{Gíriş}

Sözlük manasıyla yönetim, "yasalara, kurallara veya belli koşullara uygun biçimde çalışmayı sağlamaktır". "Yön-etmek"ten türeyen yönetim kelimesi idare ile aynı manadadır (Günel, 1995: 18). Bir şeyin kendi ekseni etrafında dönmesi manasındaki Arapça "devr" kelimesinden türeyen idare, yürütme, becerme anlamıyla kullanılmaktadır (Alpar, 1999: 101 ve Eroğlu, 2000: 5) Batıda ise "management" ve "administration" şeklinde iki biçimde kullanılan yönetim kavramı bazen de birbirleriyle aynı anlama gelecek şekilde kullanılmaktadır. Bir işi çekip çevirmek, bir örgütü belli bir hedef doğrultusunda hareket etmeye yönlendirme ilk kullanımken; kamu veya yerel yönetimi ise ikinci kullanım ifade etmektedir (Ergun, 2004: 34). Diğer bir deyişle işletme yönetimi "management" iken, kamu yönetimi ise "administration"dır (Akpınar, 2006: 14). Bu kapsamda yönetim fonksiyonları planlama, örgütleme, yöneltme, koordinasyon ve kontrol etme olup geri besleme ile birbirine bağlıdır. Kamu maliyesi, işyeri ilişkileri, hukuk, iktisat gibi bilimlerle ilişki içinde olan yönetim "disiplinler arası disiplin" şeklinde belirtilebilmektedir (Fişek, 1975: 15). Ortak hedeflere ulaşabilmek için yöneten-yönetilen, lider-izleyici gibi ilişkilerin var olduğu her ortamda yönetim kavramından söz etmek mümkündür. Yönetim kavramının insanlık kadar eski olduğunu söylemek yanlış değildir (Şimşek, 1998: 7).

Küreselleşen dünyada nüfusun gittikçe artması ve insanların ihtiyaçlarından fazlasını tüketme isteği kaynakların hızla yok olmasına neden olmaktadır. Günümüzde en önemli tehlike, ekolojik dengenin bozulması, iklim koşullarının değişmesi ve doğanın gittikçe tahrip olmasıdır. İnsanoğlunun yaşam standartlarını koruyarak devam ettirebilmesi ekolojik dengenin korunmasına ve sürdürülebilmesine bağlıdır. Ekolojik özellikler, iklim, doğal güzellikler, kültürel değerler turizm açısından çekicilik unsurlarıdır. Bir ülkede veya bir yöredeki doğal çekicilik unsurları her zaman turistlerin ilgisini çeker. Turizm sektörü, hizmet endüstrisi içinde yer almaktadır ve emek yoğun bir sektör olduğundan öznesi insandır. Bir ülkede sürdürülebilir turizm anlayışının sağlanabilmesi turizm sektöründe varllğını sürdüren işletmelerde, sürdürülebilir farkındalığın ve bilincin oluşturulmasına bağlıdır. Sürdürülebilir turizm gelişiminde turizm işletmelerinde çalışan yöneticilerin tutumları da önem arz etmektedir.

Turizm işletmeleri emek-yoğun olduğu kadar kadın-yoğun özelliğe de sahiptir. Turizm sektöründe yapılan birçok işin kadınsı olarak görülmesi (yemek pişirme, temizlik, yatak yapmak, servis yapma, karşılama) kadın çalışanların tercih edilmesine neden olmaktadır. Bununla birlikte olumlu gelişmelere rağmen kadınların turizm sektöründe en alt kademelerde çalıştırıldığı göz ardı edilmemesi gerekir. Alt kademelerde çalışmanın doğal bir sonucu olarak düşük maaş imkanı ve iş güvencesinin olmaması da olumsuz bir durum olarak önem arz etmektedir. Diğer sektörlerde olduğu gibi turizmde de dikey ve yatay olarak adlandırılan cinsiyet ayrımcılığı söz konusudur. Yatay cinsiyet ayrımcılı̆̆ı, işlerin kadınsı veya erkeksi olması görüşü ile alakalıdır. Özellikle, garson, temizlik görevlisi, oda görevlisi, satış elemanı veya karşılama işleri için kadının tercih edilmesi ile barmen, sürücü, hamal veya belboy gibi işlerde erkeklerin tercih edilmesi bu duruma örnek gösterilebilmektedir. Dikey cinsiyet ayrımcıllğında ise cinsiyet piramidi olgusu mevcuttur. Eğer turizm işletmesinde yönetici konumunda erkekler mevcut ise kadınların yükselme veya terfi etmesi zor olabilmektedir. Son yıllarda değişen şartlara rağmen turizm sektöründe, kadın çalışanların sayısının artmasına zıt olarak kadınların istedikleri konumda olmadıkları görülmektedir. Ayrıca aynı işe farklı ücret uygulamaları, baskı ve ayrımcılık gibi birçok sıkıntı ile karşı kaşıya kalan kadın çalışanlar, bir noktadan sonra sektörden ayrılmakta ya da sektörün dayatmalarını ve kurallarını kabul ederek isteksiz ve / veya verimsiz çalışabilmektedirler. 
Kadın çalışanlar çalışma hayatında cinsiyetten dolayı bazı ayrımcılıklarla karşı karşıya kalmakta olup meslek gruplarında veya işletmelerde departmanlar arasında "kadın işi" "erkek işi" olarak sinıflandırılmalara maruz kalmaktadırlar.

İşverenlere göre, bazı departmanlarda, sadece erkeklerin olması gerektiği yönünde bir düşünce hakim iken bazı departmanlarda da sadece kadınların olması görüşü hakimdir. Bunun sonucu olarak özellikle fiziksel güç isteyen ve yönetim becerisi gerektiren işlerde erkekler, temizlik, sekreterlik, ikram gibi işlerde kadınlar çalıştırılmaktadır. Fakat bu sonuçlar sadece erkeklerin kadınlara yönelik ayrımcllık yaptığı düşüncesine neden olmamalıdır.

Bu çalışmada kadın yöneticilerin, sürdürülebilir kalkınmadaki rolü ele alınmıştır. Bu kapsamda öncelikle temel kavramlar açıklanmış, ardından yarı yapılandırılmış mülakat yöntemiyle beş yıldızlı otel işletmelerinde çalışan kadınlardan toplanan veriler, nitel yöntemle analiz edilerek yorumlanmıştır.

\section{İŞLETMELERDE YÖNETIM ve YÖNETICİ TANIMLARI}

Yönetim kavramında ortak gayret, hedef ve işbirliği gibi rasyonel faaliyetler bulunmaktadır. Bundan dolayı işbirliği temelli rasyonel eylemlere yönetim demek mümkündür (Eryılmaz, 2010: 3). Yönetimi insanlık kadar eski bir "sanat", gelişen bir "bilim" ve evrensel bir "süreç" olarak nitelendirmek mümkündür. Yönetim uygulamaları sanatı, yönetimde kullanılan sistematik ve bilimsel bilgiler bilimi temsil etmektedir (Eren, 1991: 88-89).

Bir örgütün başarısız ya da başarılı olarak değerlendirilmesi çoğunlukla yöneticilerle alakalıdır. Diğer bir deyişle yöneticiler başarının ya da başarısızlığın en önemli sorumlusudur. Günümüzde yönetici durumunda olmak her emrinin yerine getirileceği manası taşımamaktadır (Aytürk, 1999: 2). Başkalarına emir verme işini sadece yöneticiler yapmazlar (Hitt, Middlemist ve Mathis, 1989: 15). Yöneticilik bulunulan örgütün yapısına göre şekillenmekte olduğundan dolayı türdeş bir iş olarak kabul edilmemektedir. Örnek vermek gerekirse, kamu yöneticisi ve özel işletme yöneticisi arasında kullanılan yöntemler açısından büyük farklılıklar görülmektedir. Diğer bir deyişle yöneticiler, "çok farklı davranışlar, tutumlar ve hatta yönetim tarzına sahiptirler." Bundan dolayı "çoğu zaman aynı olaylar karşısında farklı davranışlarla akılcı çözümler üretmeye çalıştıkları görülmektedir" (Doğan, 2001: 7).

Yöneticiler benzer eğitimler almış olup benzer kurumlarda çalışıyor olsalar dahi kullandıkları yöntemler açısından birbirlerinden ayrı düşebilmektedirler. Bundan dolayı yöneticilik işi avukat, doktor ve tüccardan farklı bir iştir. Bunun nedeni ise yöneticilerin insanla ilgilenmesi, onları bir hedefe doğru yönlendirmesi, hatta eğlendirmesi gerektiğidir. Özetle geleneksel manada yönetici "örgüt amaçlarını saptama, bu amaçlara ulaşmak için insan, madde, para ve bilgi gibi kaynakları bulma, gerekli örgütlemeyi yapma, çalışanları amaçlara ulaştırmak için kontrol etme, etkileme ve yönetme" unsurlarını örgüte entegre etmekle görevlidir (Ardanıç, 1982: 29).

Başarılı yöneticilik yapabilmek için örgüt içi ve dışı faktörleri takip etmek gerekmektedir. Değişimi öngörebilmek ve ayak uydurmak yöneticilikte oldukça önem taşımaktadır. Kısaca birçok yüzeysel iş karmaşık bir hale gelmektedir (Mintzberg, 1990: 49-61).

Yöneticilerin görevleri Drucker tarafından, örgütleme, iletişim kurma, eğitim ve hedef belirleme şeklinde ifade edilmektedir (Drucker, 1974: 713). Yönetim sürecinin temel fonksiyonları olarak kabul edilen planlama, organize etme ve kontrol etme zaman içinde farklılaşmaktadır (Acuner ve İlhan, 2002: 5). Doğal olarak "planlama, örgütleme, yöneltme, koordinasyon ve denetim süreçlerinin etkin bir şekilde kullanılması" olarak tanımlanan geleneksel yöneticilik tanımı değişmektedir. 
Yöneticiler "vizyon, destek verme, eğitim, motivasyon, liderlik, delegasyon, yaratıcılık ve sorun çözme" şeklinde yeni fonksiyonlar geliştirmektedirler. Yöneticinin "elindeki değişik araçlardan ustaca yararlanarak emrindeki personelden en iyi verim elde etmesi", "değişime ayak uydurma, yenilikçiliğe ve yaratıcılığa odaklanma" seviyesiyle ilişkilidir. Klasik yöneticilik anlayışlarını bir kenara bırakarak yeni anlayışlar geliştirmek başarılı bir yöneticinin yapması gerekenlerdendir. İş hayatında kadınların yönetici pozisyonlarında görev almaları 1970'li yılların sonuna rastlar. Yönetici olarak çalışan kadınların sayısındaki artışta belirleyici olan etkenlerin arasında siyasi alanda kadınlar lehine pozitif ayrımcılığa gidilmesi, sosyolojik yapının farklılaşması, aile fertlerinin hem ilişki seviyeleri ve niteliği hem üstlendikleri rollerin değişime uğraması yer almaktadır. Ancak kadınların kariyer hedeflerine başarıyla ulaşmalarındaki en belirgin etken hem teknik disiplinlerde hem işletme alanlarında aldıkları eğitimlerdir. Yönetici konumunda yer alan kadın sayısı 1940 ve 1950'li yıllarda oldukça düşüktür. Kadınların iş hayatında daha fazla yer edinmelerini sağlayan ilk olay 1959 yılında, kadınların ilk kez Harvard-Radcliffe işletme yönetimi programına kabul edilmeleri olmuştur. 1980 yılına gelindiğinde ise kadının iş hayatındaki varlığına yönelik bakışta olumlu anlamda bir erozyon yaşanmıştır. Bunda, 1960'lı yıllarda başlayan teknolojik yeniliklerin, kadınların eğitim düzeylerinde yaşanan artışın, kadınlara yönelik cinsiyet ayrımcılığının yavaş yavaş sona ermesinin ve tüm toplumu etkileyen bu değişimlerin kanunlarla güvence altına alınmasının büyük etkisi bulunmaktadır. Yönetici pozisyonunda görev almanın kadınlar için de normal kabul edilmesi 1980'li yıllarda mümkün olsa da bu yeni durum, kadın erkek eşitliğinin sağlanması bakımından tam anlamıyla olumlu sonuçlar vermemiştir (Arıkan, 2012: 148).

İş yaşamı daima erkeklerin elinde tuttuğu bir alan olmuştur ve kadınlar dünyanın hiçbir yerinde çalışma hayatında erkekler kadar ön planda olmamışlardır. Çoğunlukla en üst yönetsel görevlerde kadınlar az sayıda temsil edilmektedir (Barutçugil, 2002: 13). Çalışma hayatına atılan kadınların yönetim kademelerinde üstlere tırmanması ekonomik zorunluluklardan dolayı engellenmektedir (Aytaç, 1997: 222). 1980'li yıllardan bu yana iş hayatının bir şekilde içinde yer alan ve oldukça etkili roller üstlenen kadınlara, liderlik ve yöneticilik gibi pozisyon ve kademelerde hala yeteri kadar yer verilmemektedir. Buna karşın, 1990'lı yıllardan itibaren yönetici pozisyonuna yükselen kadınların sayısından olumlu bir değişim yaşanmıştır. Bu artışı, kültürel değişkenlere, teknolojide yaşanan yeniliklere ve toplumsal gelişmelere bağlamak mümkündür.

Birçok alanda yaşanan gelişme ve ilerlemelerle birlikte yönetici pozisyonundaki kadın sayısı yükselmiş olsa da bu sayı hala oldukça düşük seviyelerde seyretmektedir. İşgücünün üretimdeki yeri, istihdam oranı, kişi başına düşen milli gelir gibi faktörler ülkelerin gelişmişliğini etkilemektedir. Söz konusu gelişmişlik etmenlerinden biri de kadınların iş gücüne ne oranda katıldığıdır. Ülkelerin gelişmişliği ve verimliliği kadınların çalışma hayatına dahil edilmesiyle artış göstermektedir. Kadınlar sahip oldukları farklı yetenek ve niteliklerden dolayı örgütün eksik yönlerini tamamlamaktadırlar. Geçtiğimiz yirmi yılda çalışma hayatında karşılaşılan en önemli gelişme kadınların iş hayatına yoğun olarak girmesidir. Erkekler endüstri toplumunun çalışan profili iken, günümüz bilgi toplumunun çalışan profili ise kadınlardır. Kadınlar bilgi birikimleriyle yeni ortaya çıkan mesleklerin birçoğunda kendilerini göstermektedirler (Barutçugil, 2002: 14). Erkeklerden farklı olarak iletişim becerileri yüksek olan kadınlar sahip oldukları liderlik özellikleri ile de çalışma hayatına farklı bir bakış açısı kazandırmış ve organizasyonların eksik yanlarını tamamlamışlardır. 


\section{Kalkınma Kavramı ve Tanımları}

Literatüre dahil olduğundan beri kalkınma kavramı birçok farklı şekilde anlamlandırılmış ve tanımlanmıştır. Bugüne kadar yapılan tanımların bazılarında kavramın sadece ekonomik boyutuna değinilmiş, bazılarında ise toplumsal, kültürel ve çevresel etkenler olmadan kavramın doğru şekilde anlaşılamayacağı öne sürülmüştür. Toplumların gelişme derecelerine göre kalkınma kavramı, değişik zamanlarda değişik anlamlar yüklenerek tanımlanmıştır. Buna rağmen, kavrama, aynı dönem içinde farklı anlamlar yüklendiği de olmuştur. Bu durum, kalkınmanın içeriğinde yer alan ya da kapsadığı büyüme, sanayileşme hatta modernleşme kavramlarının kalkınmayı tanımlamak için kullanılmasına kadar gitmiştir. Kalkınma kavramı bugün sahi tam olarak anlaşılmış ve açıklıkla tanımlanmış değildir. Çoğu zaman, birçok alanda ekonomik büyümeye işaret etse de büyümenin şekliyle, yani kalkınmanın nitel mi yoksa nicel mi olduğuyla ilgili dahi bir belirsizlik hakimdir. Gerçek ise kalkınmayla kastedilen büyümenin nicel bir büyüme olmadığıdır. Kalkınma denilince ekonomik büyümeden bahsedilebileceği doğrudur ancak dikkat edilmesi gereken nokta, bu büyümenin nitelikleridir. Kalkınma kavramıyla asıl belirtilmek istenen, gelişmemiş, geri kalmış bir ekonominin canlandırılması, imkanlarının artırılması ve bunun sonucunda da o ekonomiyi ayakta tutan toplumun alım gücünün ve refahının yükseltilmesidir (Yaviloğlu, 2002: 59-76). TDK'ye göre ise, kalkınma kavramı İngilizce "development" kavramına atıf yapılarak iki şekilde tanımlanmıştır: 1- "Bir ekonomide halkın değer yargıları, dünya görüşü ile tüketim ve davranış kalıplarındaki değişmeleri içerecek biçimde toplumsal ve kurumsal yapıda dönüşüme yol açan büyüme"; 2- "Ekonomik göstergelerin yanı sıra sosyal, siyasal ve kültürel göstergelerin de ilerlemesi, yükselmesi."

"Sürdürülebilir kalkınma" kavramı ise, özellikle çevreci yaklaşımların etkisiyle ve bu yaklaşımlara sebebiyet veren doğanın tahribatı sonrası doğmuştur. 1970'li yıllarda ortaya çıkan bu kavramın öncesinde, klasik iktisatçılar tarafından doğal kaynaklar sınırsız olarak kabul edilmekteydi. O zamana kadar devletler, ekonomik faaliyetlerinde çevreci bir yaklaşım gütmeden, bir başka deyişle, çevreye verdikleri zararı umursamadan ekonomik büyüme modellerini belirlemişlerdir (Batı, 2013: 20-75). Sürdürülebilir kalkınma kavramı ilk kez 1980'li yıllarda ve uluslararası kuruluşlar tarafından yayınlanan bir rapor olarak literatürdeki yerini almıştır. Ortak Geleceğimiz (Our Common Future) adı verilen ve Birleşmiş Milletler Dünya Çevre ve Kalkınma Komisyonunca (The World Commission on Environment and Development) hazırlanan bu raporda sürdürülebilir kalkınma "Gelecek kuşakları kendi gereksinmelerini karşılama yetisinden mahrum bırakmamak koşuluyla karşılamak" olarak tanımlanmaktadır (WCED, 1987: 48). Kavramın ortaya çıkışından bu yana birçok yazar ve uzman, öncelikleri değişmekle birlikte farklı tanımlar yaparak kavramın gelişmesine katkı sağlamıştır. 2002 Dünya Sürdürülebilir Kalkınma Zirvesi'nde konuşan Mill, sürdürülebilir kalkınma hedeflerinin insani, toplumsal ve doğal sermaye ile hedefe ulaşabileceğini ve bunun için de sayılan sermayelerin daha iyi bir noktaya getirilmesi gerektiğini ifade etmiştir (Mill, 1909). Dünya Bankası ise sürdürülebilir kalkınmayı devamlılık ölçeğinde değerlendirmiş ve jenerasyonlar arasında eşitlik sağlayan bir anlayış olarak kabul etmiştir (Tıraş, 2012: 53-57). Sürdürülebilir kalkınma, bir başka raporda, Sürdürülebilir Kalkınma İçin Ulusal Stratejiler Raporunda ise “Gelecek jenerasyonların gereksinimlerini kendilerinin karşılayabilme imkanını zedelemeden bugün var olan jenerasyonun ihtiyaçlarına yönelen ekonomik ve sosyal bir yaklaşım" şeklinde tarif edilmiştir.

(Güzel vd., 2009: 24-34) ise sürdürülebilir kalkınmayı, "İnsan sağlığını ve doğal dengeyi kollayarak kesintisiz bir iktisadi büyümeye izin verecek biçimde doğal kaynakların akılcı tarzda yönetilmesi ve gelecek jenerasyonlara yaraşır bir doğa, fiziki ve sosyal bir ortam bırakma yaklaşımı" şeklinde tanımlamıştır. Bu yaklaşıma göre, çevre politikaları dikkate alınmadan yürütülen ekonomik ve sosyal politikaların bir anlamı yoktur ve kalkınmanın her aşamasında çevre gözetilmelidir (Güzel vd., 2009: 24-34). Neumayer ise sürdürülebilirliği, toplam sermayenin 
azalmadan korunması olarak tanımlamıştır. Neumayer'in sözünü ettiği toplam sermaye ise üretilen, insani, doğal ve sosyal sermayeden oluşmaktadır. "Üretilen sermaye" diye kastedilen altyapılar, makineler ve fabrikalardır. İnsan bilgi ve becerisi ise insani sermayeyi anlatır. Doğal sermaye ise insana refah sağlayan, onun sağllğı için olan, örneğin doğal kaynakların korunmasından çevrenin kirliliği emme kapasitesine kadar her şeyi içermektedir. Son olarak sosyal sermaye Neumayer için, bireylerin birbirleriyle olan etkileşimi, birlikte iş yapabilmeleri ve sosyal ilişki kurmalarını mümkün kılan huzur ortamına işaret etmektedir (Neumayer, 2004: 3). Öte yandan, Goodland ve Ledec ise sürdülebilir kalkınmayı, mevcut iktisadi ve sosyal faydaların, ileride oluşacak olası faydaları zedelemeden en doğru şekilde kullanılmasına imkan veren ekonomik dönüşüm şeklinde tarif etmiştir. Tüm bu tanımlamalardan da görüleceği üzere, kavramın tüm dünya tarafından kabul edilen ortak bir tanımı yoktur. Yine de değinilen tanımlara karşın, ortak olarak kabul gören tanımlama, Brundtland Komisyonu tarafından yapılan tanımdır (Goodland ve Ledec, 1987: 2).

\section{Kadın Yöneticilerin Sürdürülebilir Kalkınmadaki Rolü}

Uluslararası alanda gerçekleştirilen sürdürülebilir kalkınmayı sağlama girişimleri baz alındığında, Türkiye'deki gelişmelerin de benzer bir yol izlediği görülmektedir. Örneğin 1980'li yıllarda kadın hareketleri tüm dünyada bir ivme kazanıp yükselişe geçtiğinde, Türkiye'de de kadınların gönüllü olarak bir araya geldikleri oluşumların ve kurumların sayısı da artmıştır. Örneğin, 1946 yılında kurulan "Birleşmiş Milletler Kadının Statüsü Komisyonu"na benzer şekilde, Türkiye'de de 1990 yılında, “Kadının Statüsü ve Sorunları Genel Müdürlüğü" (DGSPW - Directorate General on the Status and Problems of Women) adı altında ulusal düzeyde bir mekanizma kurulması ve Türkiye'nin "Kadına Karşı Her Türlü Ayrımcılığın Ortadan Kaldırılması Sözleşmesi" (CEDAW - Convention on the Elimination of All Forms of Discrimination Against Women)'ni bazı çekincelerle de olsa imzalaması, Türkiye'nin, sürdürülebilir kalkınma ve kadına ilişkin küresel düzeyde yaşanan gelişmelerin uzağında kalmama arzusunun göstergeleridir.

Türk Ceza Kanunu'nda yapılan bazı değişiklikler de bahsi geçen feminist grupların talepleri ve çabaları ile gerçekleşmiştir. Yoğun kampanyalarla oluşturulan kamuoyundaki uzlaşma sonucunda, mağdur olmuş bir kadının, eğer fahişe olduğu kanıtlanmışsa tecavüzcüye daha az hapis cezası öngören Türk Ceza Kanunu'nun 438. Maddesi, 1990 yılında yürürlükten kaldırılmıştır. Aynı yıl Türk Medeni Kanunu'nun ayrımcı maddelerinden biri olan ve kocaya, eşinin mesleki veya sanatsal faaliyetlerini kontrol etme hakkını veren 159. Maddesi Anayasa'ya aykırı bulunarak yürürlükten kaldırılmıştır (DGSPW, 1997: 5).

Kadınların toplumdaki yerinin güçlendirilmesi amacıyla hareket eden "Kadının Statüsü ve Sorunları Genel Müdürlüğ̈̈"nün çalıştığı başlıca alanlar istihdam, eğitim, sağlık ve kadınların yaşamın her alanına eşit katılımı olmuştur. Türkiye'de güçlendirme sözcüğü başlangıçta uluslararası bağış yapan örgütler tarafından lanse edilmişti ve genellikle ekonomik bağımsızlık anlamına geliyordu ve kadınların hayatın her alanında erkeklerin gerisinde kalmasının nedeni, esas olarak gelir getirici faaliyetlere katılımlarındaki dezavantajlı konumlarından ötürü olarak kabul ediliyordu (Kardam, 2005: 86). Kadınların toplumdaki yerlerinin güçlendirilmesi planı, temelde eğitim ve sağlık alanlarında bazı girişimlerde bulunulmasına ve projeler üretilmesine neden oldu. Bunun ardındaki asıl neden, kadınların erkeklerle eşit eğitim fırsatlarına sahip olmaları halinde "resmi olarak" istihdam edilen çok daha fazla kadının olacağına yönelik inançtı. 1997'de "Kadının Statüsü ve Sorunları Genel Müdürlüğü" raporunda da açıkça belirtildiği gibi, eğitimde cinsiyet eşitsizliğinin, kadınların istihdam olanakları ve biçimleri üzerinde doğrudan bir etkisi vardı. Toplumumuzda kadınların işgücüne katılımının önemi konusunda açık bir fikir 
birliğine varılmış olmasına rağmen, kadınların kendileri, aileleri ve ülke ekonomisine katkıları için, bu konuda etkili önlemler alınmamıştır. Bu nedenle, kadınların sosyal güvenliği olan işlerdeki istihdamını artırmak, kadınların çalışma hayatına nitelikli ve vasıflı işgücü olarak girmesini sağlamak, bu amaçla gerekli eğitim programlarını geliştirmek, gerçekleştirilmesi beklenen temel hedefler olmaya devam etmektedir (DGSPW, 1997: 10).

Kadınlara karşı her türden ayrımcılığın ortadan kaldırılması, Birleşmiş Milletler Kalkınma Programı (UNDP-United Nations Development Programme)'nın da amaçları arasında yer almaktadır. UNDP’nin Toplumsal Cinsiyet Eşitliği başlığıyla eğildiği bu küresel sorunun çözümü, aynı zamanda sürdürülebilir kalkınmayı hızlandırma özelliği de taşımaktadır. Bu anlayışa göre kadınlar ve kız çocuklarına karşı her türden ayrımcılığın ortadan kaldırılması en başta temel bir insan hakkı meselesidir. Kadın ve kız çocuklarının güçlendirilmesinin, çarpan etkisi yaratma ve ekonomik büyüme ve her alanda gerçekleştirilen gelişmeyi hızlandırıcı bir rolü bulunmaktadır. UNDP, diğer BM ortakları ve uluslararası toplumun da desteğiyle, toplumsal cinsiyet eşitliğini çalışmalarının merkezine almıştır. Özellikle 2000 yılından bu yana yapılan çalışmalar sonunda, 20 yıl öncesine göre çok daha fazla kız çocuğu eğitim alabilmektedir. Çalışılan bölgelerin çoğunda ilköğretimde cinsiyet eşitliği sağlanmış durumdadır. Toplam işgücünde kadınların oranı, tarım dışı istihdamda yüzde 41'lere yükselmiştir. Bu oranın 1990 yılında yüzde 35 olduğu düşünüldüğünde sağlanan iyileştirme daha iyi anlaşılacaktır. Sürdürülebilir kalkınma hedefleri arasında kadınlar ve kız çocuklarına yönelik ayrımcılı̆̆ın her yerde ortadan kaldırılması bulunmaktadır. Hala bazı bölgelerde, özellikle işgücü piyasasında büyük eşitsizlikler bulunmaktadır ve kadınlar hala iş olanaklarına eşit düzeyde ulaşma imkanına sahip değildir. Bunun yanında, cinsel istismar ve şiddet, ücretsiz bakım ve ev işlerinin bölüşümünde eşitsizlikler ve kamu görevlendirmelerinde yaşanan ayrımclıklar sürdürülebilir kalkınmanın önündeki büyük engellerdir. Hedeflere ulaşılması bakımından, kadınların arazi ve konut gibi ekonomik kaynaklar üzerinde erkeklerle eşit haklara sahip olmasını sağlayabilmek de çok büyük önem taşımaktadır. Bugün kamu görevinde yer alan kadınların sayısı hiç olmadığı kadar yüksektir ancak kadın liderlerin sayısının artması ve teşvik edilmeleri, toplumsal cinsiyet eşitliğini daha ileriye taşıyacak politikalarla daha da mümkün hale gelecektir (UNDP, 2020).

\section{YÖNTEM}

\section{Araştırma Modeli}

Araştırmanın amacı kapsamında, İstanbul'daki beş yıldızlı otel işletmelerinde çalışan kadın yöneticilerin sürdürülebilir kalkınmadaki rolü ve sektörde yaşadıkları sıkıntıların incelenmesinde, nitel araştırma yöntemlerinden durum çalışması modeli kullanılmıştır. Durum çalışma modelinin en önemli özelliği; araştırmada ele alınan durumun, kişinin ya da topluluğun kendisine özgü özellikleri nedeniyle seçilmesi ve kendi bağlamı içinde ele alınmasıdır. Bu bağlamdan yola çıkarak durum çalışması; özel bir kişi, topluluk veya olayı incelemek için araştırmanın çalışma grubu olarak belirlenen katılımcıların tutum ya da davranışlarını ortaya çıkarmak veya davranışların sistematik biçimde açıklanmasını ortaya koymaktır (Johnson ve Christensen, 2004).

\section{Araştırmanın Çalışma Grubu}

Araştırmanın örnekleme yöntemi amaçlı örnekleme yöntemlerinden ölçüt örneklemedir. Ölçüt örnekleme, bir araştırmada gözlem birimleri belli niteliklere sahip kişiler, olaylar, nesneler ya da durumlardan oluşturulabilmektedir (Büyüköztürk vd., 2014: 92). Araştırmanın amacı 
kapsamında, İstanbul'daki beş yıldızlı otel işletmelerinde çeşitli bölümlerde yönetici pozisyonunda çalışan kadınlarla uygulama yapılmak istendiği için ölçüt örnekleme yöntemi seçilmiştir. Bu bağlamda, İstanbul'da tesadüfi yöntemle seçilmiş 10 beş yıldızlı otelde yöneticilik yapan 10 kadın katılımcıdan oluşmaktadır. Araştırmanın çalışma grubunu oluşturan katılımcılar, gönüllü olarak araştırmaya katılmışlardır. Araştırmanın çalışma grubunu oluşturan kadın yöneticiler; K1, K2 ,..., K10 şeklinde belirtilmiştir. Araştırmanın çalışma grubunu oluşturan, kadın yöneticilerin demografik özelliklerine (yaş aralığı, mesleki tecrübe) ilişkin elde edilen frekans ve yüzde dağılımları Tablo 1.'de verilmiştir.

Tablo 1. Araştırmanın Çalışma Grubunun Demografik Özelliklerine Ait Bulgular

\begin{tabular}{|c|c|c|c|}
\hline \multicolumn{2}{|c|}{ Demografik Özellikler } & (F) & $(\%)$ \\
\hline \multirow{3}{*}{ Yaş Aralığ 1} & 30-40 Yaş Arası & 3 & $\% 30$ \\
\hline & 40- 50 Yaş Arası & 5 & $\% 50$ \\
\hline & 50-60 Yaş Arası & 2 & $\% 20$ \\
\hline \multirow{4}{*}{ Mesleki Tecrübe } & 0-9 Yil & 1 & $\% 10$ \\
\hline & 10-19 Yil & 2 & $\% 20$ \\
\hline & 20-29 Yil & 5 & $\% 50$ \\
\hline & 30-39 Y1l & 2 & $\% 20$ \\
\hline \multicolumn{2}{|c|}{ Toplam } & 10 & $\% 100$ \\
\hline
\end{tabular}

Tablo 1.'e göre araştırmanın çalışma grubunu oluşturan katılımcıların yaş aralıkları; \%30 (3 kişi)'u 30-40 yaş arası, \%50 (5 kişi)'si 40-50 yaş arası ve \%20 (2 kişi)'si 50-60 yaş arasıdır. Mesleki tecrübelerine göre ise; \%10 (1 kişi)'u 0-9 yıl, \%20 (2 kişi)'si 10-19 yıl, \%50 (5 kişi)'si 20-29 yıl ve \%20 (2 kişi)'si 30-39 yıldır. Bu duruma göre; araştırmanın çalışma grubunu oluşturan kadın yöneticilerin çoğunluğunun yaş aralığının \%50' lik dilimle 40-50 yaş grubunun oluşturduğunu ve 20 ile 29 yıl arasında mesleki tecrübeye sahip kişilerden meydana geldiğini söylemek mümkündür.

\section{Araştırmanın Veri Toplama Araçları}

Araştırmanın veri toplama aracı olarak İstanbul' daki beş yıldızlı otel işletmelerinde çalışan kadın yöneticilerin sürdürülebilir kalkınmadaki rolü ve sektörde yaşadıkları sıkıntıların ele alındığ görüşme soruları hazırlanmıştır. Çalışmada, güvenilirlik açısından otel isimleri kullanılmamaktadır. Bu bağlamda, araştırmanın veri toplama aracı, araştırmanın çalışma grubunun demografik özelliklerini (yaş aralığı, mesleki tecrübe, çalışılan oteller) belirlemeye yönelik 4 soru, turizm sektöründe kadın yöneticilerin yaşadıkları sıkıntılara ilişkin yarı yapılandırılmış açık uçlu 7 sorudan oluşan görüşme formu kullanılmıştır. Bu sorular aşağıda verilmiştir: 
- Kaç yıldır otelde yönetici pozisyonunda çalışıyorsunuz?

- Otelde yönetici olmadan önceki hedefler,

- Otelde yönetici olmadan önceki kadın olarak yaşadıkları sıkıntılar-olumsuzluklar,

- Otelde yönetici pozisyonuna geçtiklerinde yaşadıkları sıkıntılar,

- Otelde yönetici olunduğunda erkek yöneticilerin ve takım arkadaşlarının tutum ve davranışları (olumlu-olumsuz),

- Otelde yönetici olunduğunda diğer kadın yönetici ve takım arkadaşlarının tutum ve davranışları (olumlu-olumsuz),

- Gelecekte kadın yönetici olacak kadınlara tavsiyeleriniz nelerdir?

\section{Verilerin Toplanması}

Veriler görüşme tekniğiyle toplanmıştır. Görüşme tekniği, eğitim alanında en yaygın kullanılan görüşme türlerinden biridir. Birebir görüşmeler katılımcıların düşüncelerinin rahat ve açık bir şekilde ifade edilmesine olanak sağlayan ideal görüşmelerdir (Creswell, 2014). Araştırma İstanbul İli sınırları içinde gönüllü katılımcıya uygun bir mekanda yüz yüze ve katılımcıların rızasıyla ses kaydı ve not alınarak 27.02.2020- 04.03.2020 tarihleri arasında toplanmıştır. Görüşmeler ortalama yaklaşık 30 dakika sürmüştür.

\section{Verilerin Toplanmasi}

Araştırmada elde edilen verilerin analizinde içerik analiz kullanılmıştır. Bu analizin amacı, elde edilen verilerin araştırma kapsamındaki kavramalara ve ilişkilere ulaşılmasını sağlamaktadır. Buna göre, birbirine benzeyen verileri belirli kavramlar ve temalar çerçevesinde bir araya getirerek, bunların okuyucunun anlayabileceği bir biçimde organize ederek yorumlanmasını sağlamaktadır (Yıldırım ve Şimşek, 2018: 107). İçerik analizi, Thomas ve Hardene (2008) tarafından kullanılan analiz aşamaları kullanılarak veriler nitel veri analiz programı MAXQDA 2018 kullanılarak yapılmıştır. Bu aşamalar aşağıda açıklanmıştır:

- Bulguların Kodlanması: Bu aşamada birincil araştırmalardan çıkarılan doğrudan alıntılar ya da temel kavramlar şeklindeki bulgular, satır satır okunarak kodlanmaktadır. Bütün bulgular kodlandıktan sonra ikinci aşamaya geçilebilir.

- Betimleyici Temaların Geliştirilmesi: Bu aşamada elde edilen kodlar benzerlik ve farklılıklarına göre karşılaştırılarak hiyerarşik bir ağaç yapısı oluşturacak şekilde gruplandırılır. Oluşturulan her gruba tema adı verilmektedir. Her tema, gruplanmış kodların tanımlarını ve anlamlarını kapsayacak şekilde oluşturulmaktadır.

- Analitik Temaların Üretilmesi: Bu aşama, temaların geliştirilmesi sürecinde birincil çalışmaların bulgularına yakın kalınırken, analitik temaların üretilmesi sürecinde birincil çalışmaların ötesine geçilerek yeni yorumlayıcı yapılar ve açıklamalar üretilmektedir. Birincil çalışmaların ötesine geçme, bir süreliğine askıya alman araştırma sorularının cevaplanması için tüme varımsal analiz sonucu elde edilen betimleyici temaların kullanılmasını gerektirmektedir. Bu amaçla betimleyici temaların karşılaştırılması ve başka araştırmacılarla tartışılması sonucu, daha soyut olan analitik temalar oluşturulmaktadır.

- Geçerlik ve Güvenirliği Sağlama Aşaması: Bir araştırmanın bilimsel bir çalışma olarak kabul edilmesinde en önemli unsur güvenilirlik ve geçerliliğidir. Nitel araştırma tekniklerinde; toplanan verilerin ayrıntılı olarak incelenmesi, araştırmacının sonuçlara nasıl ulaşttğını açıklamasında geçerliğin önemli ölçütleri arasında yer almaktadır (Yıldırım ve Şimşek, 2018). 
Temalar ilgili literatüre dayalı olarak belirlenmiş, kodlar çıkartılmış ve nitel araştırmaya uygun bir içerik çözümlemesi yapılmaya çalışılmış ve bulgular sunulmuştur. Elde edilen veriler, çalışmanın amaçları doğrultusunda temalar ve alt temalar tanımlanarak analiz edilmiştir. Bu çalışmada, elde edilen veriler, araştırmanın güvenirliğinin sağlanması için veriler iki uzman görüşüne başvurulmuştur. Miles ve Huberman (1994)'ın güvenirlik formülünden faydalanılmıştır. Formül aşağıda verilmiştir:

Güvenirlik = [Görüş Birliği / (Görüş Birliği + Görüş Ayrılı̆̆ı) $)$ x 100

$$
=[73 /(73+8)] \times 100=[73 / 81] \times 100=[0,9012] \times 100=90,12
$$

Miles ve Huberman (1994)'ın güvenirlik formülü sonucunda \%90 çıkmıştır. Miles ve Huberman (1994)'a göre \%70 ve yukarısında çıkan araştırma sonuçlarının güvenirliliğinin yüksek olduğunu belirtmişlerdir.

\section{BULGULAR}

Bu bölümde, araştırmanın amacı kapsamında veri toplama aracından elde edilen bulgular ve yorumlara ilişkin bilgiler yer almaktadır.

\section{Araştırmanın Çalışma Grubunu Oluşturan Katılımcıların Otelde Yönetici Pozisyonunda Çalışma Sürelerine Ait Bulgular}

Araştırmanın çalışma grubunu oluşturan katılımcıların otelde yönetici pozisyonunda çalışma sürelerine ait bulgular Tablo 2.'de verilmiştir.

Tablo 2. Araştırmanın Çalışma Grubunu Oluşturan Katılımcıların Otelde Yönetici Pozisyonunda Çalışma Sürelerine Ait Bulgular

\begin{tabular}{lcc}
\hline $\begin{array}{l}\text { Katılımcıların Otelde Yönetici Pozisyonunda Çalışma } \\
\text { Süreleri }\end{array}$ & (F) & (\%) \\
\hline $1-10$ Yıl Arası & 7 & $\% 70$ \\
\hline $11-20$ Yıl Arası & 2 & $\% 20$ \\
\hline $21-30$ Yıl Arası & 1 & $\% 10$ \\
\hline Toplam & $\mathbf{1 0}$ & $\mathbf{\% 1 0 0}$ \\
\hline
\end{tabular}

Tablo 2.'ye göre, araştırmanın çalışma grubunu oluşturan katılımcıların otelde yönetici pozisyonunda çalışma sürelerine ait bulgular; \%70 (7 kişi)'i 1-10 yıl arası, \%20 (2 kişi)'si 11-20 yıl arası ve \%10 (1 kişi)'u 21-30 yıl arasıdır. Kadın yöneticilerin yönetici olarak \%70 oranında 1-10 yıl arasında çalıştığı gözlemlenmektedir. 


\section{Araştırmanın Çalışma Grubunu Oluşturan Katılımcıların Otelde Yönetici Olmadan Önceki Hedefleri Hakkındaki Görüşlerine Ait Bulgular}

Araştırmanın çalışma grubunu oluşturan katılımcıların otelde yönetici olmadan önceki hedefleri hakkındaki görüşlerine ait bulgular Tablo 3.'te verilmiştir.

Tablo 3. Araştırmanın Çalışma Grubunu Oluşturan Katılımcıların Otelde Yönetici Olmadan Önceki Hedefleri Hakkındaki Görüşlerine Ait Bulgular

\begin{tabular}{|c|c|c|}
\hline $\begin{array}{l}\text { Katılımcıların Otelde Yönetici Olmadan } \\
\text { Önceki Hedefleri Hakkındaki Görüşleri }\end{array}$ & (F) & (\%) \\
\hline $\begin{array}{l}\text { Yönetici Olmak } \\
\text { İstemeyenler }\end{array}$ & 1 & $\% 10$ \\
\hline $\begin{array}{c}\text { Satış Departmanı } \\
\text { Yöneticisi Olmak } \\
\text { İsteyenler }\end{array}$ & 2 & $\% 20$ \\
\hline $\begin{array}{l}\text { Mali İşler Yöneticisi } \\
\text { Olmak İsteyenler }\end{array}$ & 1 & $\% 10$ \\
\hline $\begin{array}{l}\text { Yönetici Olmak } \\
\text { İsteyenler }\end{array}$ & 3 & $\% 30$ \\
\hline $\begin{array}{c}\text { Seyahat } \\
\text { Acentesinde Kariyer } \\
\text { Hedefi Olanlar }\end{array}$ & 1 & $\% 10$ \\
\hline $\begin{array}{l}\text { Aileden Gelen } \\
\text { Mesleki } \\
\text { Heyecan/İstek }\end{array}$ & 1 & $\% 10$ \\
\hline $\begin{array}{l}\text { Kat Hizmetleri } \\
\text { Yöneticisi Olmak } \\
\text { İsteyenler }\end{array}$ & 1 & $\% 10$ \\
\hline Toplam & 10 & $\% 100$ \\
\hline
\end{tabular}

Tablo 3.'e göre, araştırmanın çalışma grubunu oluşturan katılımcıların otelde yönetici olmadan önceki hedefleri hakkındaki görüşleri bir bütün olarak ele alındığında işlev ve kavram yönüyle 1 kategori açısından değerlendirilmiştir. Bunlar; Kariyer Hedefi (10)'dur.

Kariyer Hedefi (10) kategorisindeki katılımcıların cevaplarından oluşturulan temalar; Yönetici Olmak İstemeyenler (1), Satış Departmanı Yöneticisi Olmak İsteyenler (2), Mali İşler Yöneticisi Olmak İsteyenler (1), Yönetici Olmak İsteyenler (3), Seyahat Acentesinde Kariyer Hedefi Olanlar (1), Aileden Gelen Mesleki Heyecan/İstek (1) ve Kat Hizmetleri Yöneticisi Olmak İsteyenler (1)'dir. 
Kadın yöneticilerin yönetici olmadan önce kariyer hedefi olarak belirledikleri yönetici olma istekleri (F) 3 olarak ve \%30 oranında olduğu Tablo 3'ten görülmektedir.

\section{Araştırmanın Çalışma Grubunu Oluşturan Katılımcıların Otelde Yönetici Olmadan Önceki Kadın Olarak Yaşadıkları Sıkıntılar-Olumsuzluklar Hakkındaki Görüşlerine Ait Bulgular}

Araştırmanın çalışma grubunu oluşturan katılımcıların otelde yönetici olmadan önceki kadın olarak yaşanılan sıkıntılar-olumsuzluklar hakkındaki görüşlerine ait bulgular Tablo 4.'te verilmiştir.

Tablo 4. Araştırmanın Çalışma Grubunu Oluşturan Katılımcıların Otelde Yönetici Olmadan Önceki Kadın Olarak Yaşadıkları Sıkıntılar-Olumsuzluklar Hakkındaki Görüşlerine Ait Bulgular

\begin{tabular}{|c|c|c|}
\hline $\begin{array}{c}\text { Katılımcıların Otelde Yönetici Olmadan Önceki } \\
\text { Kadın Olarak Yaşadıkları Sıkıntılar-Olumsuzluklar } \\
\text { Hakkındaki Görüşleri }\end{array}$ & (F) & $(\%)$ \\
\hline Sıkıntı Yaşamayıp Destek Görenler & 2 & $\% 13,33$ \\
\hline \multirow{8}{*}{$\begin{array}{c}\text { Yaşanılan } \\
\text { Sıkıntılar/Olumsuzluklar }\end{array}$} & 1 & $\% 6,66$ \\
\hline & 3 & $\% 20$ \\
\hline & 1 & $\% 6,66$ \\
\hline & & \\
\hline & 2 & $\% 13,33$ \\
\hline & 3 & $\% 20$ \\
\hline & 1 & $\% 6,66$ \\
\hline & 2 & $\% 13,33$ \\
\hline Toplam & 15 & $\% 100$ \\
\hline
\end{tabular}

Tablo 4.'e göre, araştırmanın çalışma grubunu oluşturan katılımcıların otelde yönetici olmadan önceki kadın olarak yaşadıkları sıkıntılar-olumsuzluklar hakkındaki görüşleri bir bütün olarak ele alındığında işlev ve kavram yönüyle 2 farklı kategori açısından değerlendirilmiştir. Bunlar; Sıkıntı Yaşamayıp Destek Görenler (2) ve Yaşanılan Sıkıntılar/Olumsuzluklar (13)'dır Yaşanılan Sıkıntılar/Olumsuzluklar (13) kategorisindeki katılımcıların cevaplarından oluşturulan temalar; Çalışma Saatleri (1), Cinsiyet (3), Çalışma Koşulları (1), Medeni Durumdan Kaynaklı Ailevi 
Sebepler (2), Sözlü/ Fiziksel Taciz (3), Dış Görünüş/Bakımlı Olmak (1) ve Yıldırma Davranışları/Mobbing (2)'dir.

Beş yıdızlı otellerde çalışan kadınların kadın olduklarından dolayı bir cinsiyet ayırımına maruz kaldıkları tablodan da cinsiyet (F)3 ve \%20 olarak görülmektedir. Ayrıca sözlü/fiziksel tacize uğradıkları da verilerden anlaşılmaktadır. Buna rağmen sıkıntı yaşamayıp çalışma arkadaşlarından destek görenlerin oranı ile yıldırma davranışı/mobing'e uğrayanların oranı da $\% 13.33$ olarak tespit edilmiştir.

\section{Araştırmanın Çalışma Grubunu Oluşturan Katılımcıların Otelde Yönetici Pozisyonuna Geçtiklerinde Yaşadıkları Sıkıntılar Hakkındaki Görüşlerine Ait Bulgular}

Araştırmanın çalışma grubunu oluşturan katılımcıların otelde yönetici pozisyonuna geçtiklerinde yaşadıkları sıkıntılar hakkındaki görüşlerine ait bulgular Tablo 5.'te verilmiştir.

Tablo 5. Araştırmanın Çalışma Grubunu Oluşturan Katılımcıların Otelde Yönetici Pozisyonuna Geçtiklerinde Yaşadıkları Sıkıntılar Hakkındaki Görüşlerine Ait Bulgular

\begin{tabular}{|c|c|c|c|}
\hline \multicolumn{2}{|c|}{$\begin{array}{c}\text { Katılımcıların Otelde Yönetici Pozisyonuna } \\
\text { Geçtiklerinde Yaşadıkları Sıkıntılar Hakkındaki } \\
\text { Görüşleri }\end{array}$} & (F) & $(\%)$ \\
\hline \multicolumn{2}{|c|}{ Sıkıntı Yaşamayıp Destek Görenler } & 4 & $\% 30,78$ \\
\hline \multirow{7}{*}{$\begin{array}{c}\text { Yaşanılan } \\
\text { Sıkıntılar/Olumsuzluklar }\end{array}$} & Sözlü/ Fiziksel Taciz & 1 & $\% 7,69$ \\
\hline & Diğer Personellerin & & \\
\hline & $\begin{array}{l}\text { Olumsuz Tutum ve } \\
\text { Davranışları }\end{array}$ & 2 & $\% 15,38$ \\
\hline & Cinsiyet & 2 & $\% 15,38$ \\
\hline & $\begin{array}{l}\text { Medeni Durumdan } \\
\text { Kaynaklı Ailevi } \\
\text { Sebepler }\end{array}$ & 2 & $\% 15,38$ \\
\hline & $\begin{array}{l}\text { Mezuniyet Alanının } \\
\text { Farklı Olması }\end{array}$ & 1 & $\% 7,69$ \\
\hline & $\begin{array}{c}\text { Yıldırma } \\
\text { Davranışları/Mobbing }\end{array}$ & 1 & $\% 7,69$ \\
\hline \multicolumn{2}{|c|}{ Toplam } & 13 & $\% 100$ \\
\hline
\end{tabular}

Tablo 5.'e göre, araştırmanın çalışma grubunu oluşturan katılımcıların otelde yönetici pozisyonuna geçtiklerinde yaşadıkları sıkıntılar hakkındaki görüşleri bir bütün olarak ele alındığında işlev ve kavram yönüyle 2 farklı kategori açısından değerlendirilmiştir. Bunlar; Sıkıntı Yaşamayıp Destek Görenler (4) ve Yaşanılan Sıkıntılar/Olumsuzluklar (9)'dır. 
Yaşanılan Sıkıntılar/Olumsuzluklar (9) kategorisindeki katılımcıların cevaplarından oluşturulan temalar; Sözlü/ Fiziksel Taciz (1), Diğer Personellerin Olumsuz Tutum ve Davranışları (2), Cinsiyet (2), Medeni Durumdan Kaynaklı Ailevi Sebepler (2), Mezuniyet Alanının Farklı Olması (1) ve Yıldırma Davranışları/Mobbing (1)'dir.

Güvenilirlik açısından otel isimlerine yer verilmemektedir. Ancak yapılan yüz yüze görüşmede kurumsal zincir otellerde çalışan kadın yöneticilerin yöneticiliklerinde sıkıntı yaşamadıkları aksine destek gördükleri tespit edilmiştir. Sıkıntı yaşamayıp destek görenlerin oranı \%30,78 ile tablo' dan da takip edilebilmektedir.

\section{Araştırmanın Çalışma Grubunu Oluşturan Katılımcıların Otelde Yönetici Olunduğunda Erkek Yöneticilerin ve Takım Arkadaşlarının Tutum ve Davranışları (Olumlu-Olumsuz) Hakkındaki Görüşlerine Ait Bulgular}

Araştırmanın çalışma grubunu oluşturan katılımcıların otelde yönetici olunduğunda erkek yöneticilerin ve takım arkadaşlarının tutum ve davranışları (olumlu-olumsuz) hakkındaki görüşlerine ait bulgular Tablo 6.'da verilmiştir.

Tablo 6. Araştırmanın Çalışma Grubunu Oluşturan Katılımcıların Otelde Yönetici Olunduğunda Erkek Yöneticilerin ve Takım Arkadaşlarının Tutum ve Davranışları (OlumluOlumsuz) Hakkındaki Görüşlerine Ait Bulgular

\begin{tabular}{|c|c|c|c|}
\hline \multicolumn{2}{|c|}{$\begin{array}{l}\text { Katılımcıların Otelde Yönetici } \\
\text { Olunduğunda Erkek Yöneticilerin ve Takım } \\
\text { Arkadaşlarının Tutum ve Davranışları } \\
\text { (Olumlu-Olumsuz) Hakkındaki Görüşleri }\end{array}$} & $(F)$ & $(\%)$ \\
\hline $\begin{array}{l}\text { Olumlu Tutum ve } \\
\text { Davranışlar }\end{array}$ & $\begin{array}{l}\text { Sorun Yaşamayıp } \\
\text { Destek Görenler }\end{array}$ & 5 & $\% 33,33$ \\
\hline \multirow{5}{*}{$\begin{array}{l}\text { Olumsuz Tutum ve } \\
\text { Davranışlar }\end{array}$} & $\begin{array}{l}\text { Medeni Durumdan } \\
\text { Kaynaklı Ailevi } \\
\text { Sebepler }\end{array}$ & 2 & $\% 13,33$ \\
\hline & $\begin{array}{c}\text { Yıldırma } \\
\text { Davranışları/Mobbing }\end{array}$ & 2 & $\% 13,33$ \\
\hline & Cinsiyet & 1 & $\% 6,66$ \\
\hline & Sözlü Taciz & 2 & $\% 13,33$ \\
\hline & $\begin{array}{l}\text { Diğer Personellerin } \\
\text { Olumsuz Tutum ve } \\
\text { Davranışları }\end{array}$ & 1 & $\% 6,66$ \\
\hline \multicolumn{2}{|c|}{$\begin{array}{l}\text { Olumlu Ya Da Olumsuz Tutum Davranış } \\
\text { Yaşamayanlar }\end{array}$} & 2 & $\% 13,33$ \\
\hline \multicolumn{2}{|c|}{ Toplam } & 15 & $\% 100$ \\
\hline
\end{tabular}


Tablo 6.'ya göre, araştırmanın çalışma grubunu oluşturan katılımcıların otelde yönetici olunduğunda erkek yöneticilerin ve takım arkadaşlarının tutum ve davranışları (olumluolumsuz) hakkındaki görüşleri bir bütün olarak ele alındığında işlev ve kavram yönüyle 3 farklı kategori açısından değerlendirilmiştir. Bunlar; Olumlu Tutum ve Davranışlar (5), Olumsuz Tutum ve Davranışlar (8) ve Olumlu Ya Da Olumsuz Tutum Davranış Yaşamayanlar (2)'dır.

Olumlu Tutum ve Davranışlar (5) kategorisindeki katılımcıların cevaplarından oluşturulan tema; Sorun Yaşamayıp Destek Görenler (5)'dir.

Kadın yöneticiler erkek yöneticiler tarafından sorun yaşamadıklarını bilakis destek gördüklerini $\% 33,33$ oranda ifade etmişlerdir. Yapılan yüz yüze görüşmelerde olumsuz davranış görenlerin genelde kurumsal olmayan işveren sahibi otellerde çalışan yönetici kadınlar olduğu \%13,33 olarak tespit edilmiştir.

\section{Araştırmanın Çalışma Grubunu Oluşturan Katılımcıların Otelde Yönetici Olunduğunda Kadın Yöneticilerin ve Takım Arkadaşlarının Tutum ve Davranışları (Olumlu-Olumsuz) Hakkındaki Görüş̧lerine Ait Bulgular}

Araştırmanın çalışma grubunu oluşturan katılımcıların otelde yönetici olunduğunda kadın yöneticilerin ve takım arkadaşlarının tutum ve davranışları (olumlu-olumsuz) hakkındaki görüşlerine ait bulgular Tablo 7.'de verilmiştir.

Tablo 7. Araştırmanın Çalışma Grubunu Oluşturan Katılımcıların Otelde Yönetici Olunduğunda Kadın Yöneticilerin ve Takım Arkadaşlarının Tutum ve Davranışları (OlumluOlumsuz) Hakkındaki Görüşlerine Ait Bulgular

Katılımcıların Otelde Yönetici Olunduğunda

Kadın Yöneticilerin ve Takım Arkadaşlarının

Tutum ve Davranışları (Olumlu-Olumsuz)

Hakkındaki Görüşleri

\begin{tabular}{|c|c|c|c|}
\hline $\begin{array}{l}\text { Olumsuz Tutum ve } \\
\text { Davranışlar }\end{array}$ & $\begin{array}{l}\text { Hemcinslerin } \\
\text { Olumsuz Tutum ve } \\
\text { Davranışları }\end{array}$ & 10 & $\% 83,33$ \\
\hline $\begin{array}{l}\text { Olumlu Tutum ve } \\
\text { Davranışlar }\end{array}$ & $\begin{array}{l}\text { Sorun Yaşamayıp } \\
\text { Destek Görenler }\end{array}$ & 1 & $\% 8,33$ \\
\hline \multicolumn{2}{|c|}{$\begin{array}{c}\text { Olumlu Ya Da Olumsuz Tutum Davranış } \\
\text { Yaşamayanlar }\end{array}$} & 1 & $\% 8,33$ \\
\hline \multicolumn{2}{|c|}{ Toplam } & 12 & $\% 100$ \\
\hline
\end{tabular}

Tablo 7.'ye göre, araştırmanın çalışma grubunu oluşturan katılımcıların otelde yönetici olunduğunda kadın yöneticilerin ve takım arkadaşlarının tutum ve davranışları (olumluolumsuz) hakkındaki görüşleri bir bütün olarak ele alındığında işlev ve kavram yönüyle 3 farklı kategori açısından değerlendirilmiştir. Bunlar; Olumsuz Tutum ve Davranışlar (10), Olumlu Tutum ve Davranışlar (1) ve Olumlu Ya Da Olumsuz Tutum Davranış Yaşamayanlar (1)'dır. 
Olumsuz Tutum ve Davranışlar (10) kategorisindeki katılımcıların cevaplarından oluşturulan temalar; Medeni Durumdan Kaynaklı Ailevi Sebepler (2), Yıldırma Davranışları/Mobbing (2), Cinsiyet (1), Sözlü Taciz (2), Diğer Personellerin Olumsuz Tutum ve Davranışları (1)'dir.

Olumlu Tutum ve Davranışlar (5) kategorisindeki katılımcıların cevaplarından oluşturulan tema; Sorun Yaşamayıp Destek Görenler (5)'dir.

Kadın yöneticilerin takım arkadaşı olarak çalıştıkları hemcinsleri olan kadınlardan \%83,33 ile olumsuz davranış gördükleri tablo'dan da takip edilebilmektedir. Burada da kıskançlık duygusunun ağır bastığı yine mülakatta kadın yöneticiler tarafından ifade edilmiştir.

\section{Araştırmanın Çalışma Grubunu Oluşturan Katılımcıların Gelecekte Kadın Yönetici Olacak Kadınlara Tavsiyeleri Hakkındaki Görüşlerine Ait Bulgular}

Araştırmanın çalışma grubunu oluşturan katılımcıların gelecekte kadın yönetici olacak kadınlara tavsiyeleri hakkındaki görüşlerine ait bulgular Tablo 8.'de verilmiştir.

Tablo 8. Araştırmanın Çalışma Grubunu Oluşturan Katılımcıların Gelecekte Kadın Yönetici Olacak Kadınlara Tavsiyeleri Hakkındaki Görüşlerine Ait Bulgular

\begin{tabular}{|c|c|c|c|}
\hline \multicolumn{2}{|c|}{$\begin{array}{c}\text { Katılımcıların Gelecekte Kadın Yönetici } \\
\text { Olacak Kadınlara Tavsiyeleri Hakkındaki } \\
\text { Görüşleri }\end{array}$} & \multirow{2}{*}{$\begin{array}{l}\text { (F) } \\
1\end{array}$} & \multirow{2}{*}{$\begin{array}{c}\text { (\%) } \\
\% 6,25\end{array}$} \\
\hline \multirow{5}{*}{$\begin{array}{l}\text { İçsel Motivasyon } \\
\text { Kaynakları }\end{array}$} & Sorumluluk Bilinci & & \\
\hline & $\begin{array}{l}\text { Zor İşlerin Üstesinden } \\
\text { Gelmek }\end{array}$ & 6 & $\% 37,50$ \\
\hline & Bireysel Başarı & 3 & $\% 18,75$ \\
\hline & $\begin{array}{c}\text { Diş Görünüş/Bakımlı } \\
\text { Olmak }\end{array}$ & 1 & $\% 6,25$ \\
\hline & $\begin{array}{l}\text { Sektörde Kendilerini } \\
\text { Geliştirecek Eğitim } \\
\text { Almaları }\end{array}$ & 2 & $\% 12,50$ \\
\hline \multirow{3}{*}{$\begin{array}{l}\text { Dışsal Motivasyon } \\
\text { Kaynakları }\end{array}$} & Üst Makamların İlgisi & 1 & $\% 6,25$ \\
\hline & $\begin{array}{c}\text { Çalışma Ortamında } \\
\text { Görevin Ön Planda } \\
\text { Tutulduğu Algisının } \\
\text { Yansitılması }\end{array}$ & 1 & $\% 6,25$ \\
\hline & $\begin{array}{l}\text { Dış Kaynaklı Destek } \\
\text { Almak }\end{array}$ & 1 & $\% 6,25$ \\
\hline \multicolumn{2}{|c|}{ Toplam } & 16 & $\% 100$ \\
\hline
\end{tabular}


Tablo 8.'e göre, araştırmanın çalışma grubunu oluşturan katılımcıların gelecekte kadın yönetici olacak kadınlara tavsiyeleri hakkındaki görüşleri bir bütün olarak ele alındığında işlev ve kavram yönüyle 2 farklı kategori açısından değerlendirilmiştir. Bunlar; İçsel Motivasyon Kaynakları (13) ve İçsel Motivasyon Kaynakları (3)'dır.

İçsel Motivasyon Kaynakları (13) kategorisindeki katılımcıların cevaplarından oluşturulan temalar; Sorumluluk Bilinci (1), Zor İşlerin Üstesinden Gelmek (6), Bireysel Başarı (3), Dış Görünüş/Bakımlı Olmak (1) ve Sektörde Kendilerini Geliştirecek Eğitim Almaları (2)'dır.

Kadınların turizm sektöründe yönetici olarak çalışacak diğer kadınlara tavsiyelerine bakıldığında; yılmadan zorlukların üstesinden gelmelerini öğütledikleri tablodan da \%37,50 oran ile görmek mümkündür.

Araştırmanın genel bulguları değerlendirildiğinde katılımcıların yöneticiyi olmayı \% 30 oranla hedefledikleri görülmektedir. Katılımcıların çoğu yönetici olmadan önce işleriyle ilgili sıkıntılar yaşamışlardır. Bunların büyük kısmı cinsiyet temellidir (bkz. Tablo 4). Katılımclar yönetici olarak çalışmaya başladıktan sonra da yaşadıkları sıkıntıların çoğunun cinsiyet temelli olduğu görülmektedir (bkz. Tablo 5). Kadın yöneticilerin, yönetici olduktan sonra erkek yönetici ve takım arkadaşlarından gördükleri olumsuz davranışlar, olumlulara ya da olumlu-olumsuz olmayanlara göre daha fazladır. Aynı durum, hemcinsleri için de geçerlidir. Katılımcıların gelecekte yönetici olacak kadınlara önerilerine bakıldığında en fazla "zor işlerin üstesinden gelmek" önerisinde bulundukları görülmektedir.

\section{SONUÇ}

Öznesi insan olan turizm sektörü emek-yoğun olma özelliği nedeniyle çalışma koşulları diğer sektörlere göre farklılık gösteren bir sektördür. Özellikle bireyler tatil yaparken ve bayram, yılbaşı gibi diğer özel günlerde çalışma zorunluluğunun olması hem kadın hem erkek çalışanlar açısından bir hayli yoğun mesai gerektirmektedir. Kadın çalışan ve kadın yönetici olan kişilerin aile hayatlarından ve çocuklarından uzak kalması eş ve çocuklar açısından da sorun yaratabilmektedir. Çalışmada, yüz yüze yapılan görüşmede kadın yöneticiler, özellikle bebek bekledikleri hamilelik döneminde; rahatsızlanabilecekleri, izin alabilecekleri veya doğum iznine çıkacaklarından dolayı işin yarım kalabileceği ve bu süreçte diğer çalışanlara fazla yük binebileceği hususundan dolayı gizli bir mobing gördüklerini de belirtmişlerdir. Bu nedenle bazı kadın yöneticiler "anne" olmayı bile ertelemiş veya kariyerlerinde yükselmeyi tercih ettiklerinden çocuk sahibi olmayı istemediklerini belirtmişlerdir. Ancak sektörde çalışmak isteyen kadınlar yine de zoru başarmak azminden yola çıarak hedeflerine ulaşmak için gayret göstermektedirler. Yapılan çalışmada turizm sektöründe kadın yönetici olarak çalışmanın güçlüklerle dolu olduğu vurgulanmaktadır. İse yapılan başvurularda öncelikle düzgün fiziğe sahip olmanın önemli olduğu, akıcı ve Türkçeyi doğru kullanarak konuşmanın ve ikna yeteneğinin olması hususunun öneminden bahsetmişlerdir. Yoğun çalışma koşullarıyla birlikte bazı erkek yöneticilerde bulunduğu kadrodan yönetici olarak çıan kadının o görevi dolduramayacağı veya o görevi layıkıyla yapamayacağı fikrinin hakim olduğu belirtilmiştir. Kurumsal veya uluslararası zincir otellerde çalışan kadın yöneticiler ise çalışma koşullarının daha anlayışlı, objektif ve erkek çalışma arkadaşları veya yöneticilerinden destek gördükleri şeklinde ifade etmişlerdir. Bu otellerde kadın yöneticiler çalışma hayatında olumsuzluk yaşamadıklarını ve zevkle çalıştıklarını belirtmişlerdir.

Kadınların çalışma hayatı içerisinde yer alması toplumların gelişmişlik düzeyleri ile de ilgilidir. Her alanda, her platformda söz sahibi olmak isteyen kadınlar desteklenmelidir. Kendini eğitim ile geliştiren ve donatan kadın, hem iş hayatında hem de evde çocuklarına da 1şık olabilecektir. 
Nitekim Birleşmiş Milletler UNDP 2030 Sürdürülebilir Kalkınma Amaçlarında kadınların toplumda güçlenmelerine yönelik çalışmalar olması gerektiği vurgulanmaktadır. Ülkemizde de gerek iş hayatında gerek tarlada, gerek evde çalışan kadınların ekonomiye katkılarının olduğu da bir gerçektir. Evde iken sosyal ağlardan el işi yaparak geçimlerini sürdürmeye çalışan birçok kadın da bulunmaktadır. Günümüzde teknolojinin ilerlemesi ile birlikte kadınlar internet ortamını bilinçli kullanarak iş olanakları da yaratabilmektedirler. Daha fazla kadının iş hayatına katılımını desteklemek ve olanaklar sunmak gerekmektedir. Toplumda kadına gereken önem, değer ve saygının verilebilmesi için sivil toplum kuruluşları, belediyeler işbirliği içerisinde olarak kadınların mesleki olarak yetiştirilmesine yönelik kurslar düzenlenmesine öncülük etmelidir. Ayrıca görsel medyanın etkisi insanlar üzerinde son derece etkilidir. Kadına karşı saygı ve sevgi dolu davranışlar konusunda çeşitli eğitim programları düzenlenerek toplumun bilinçlendirilmesi gerekmektedir. Kadın yöneticilerin başarılarını paylaşıp destek olmak diğer kadınlar üzerinde de teşvik edici unsur olabilecektir.

\section{KAYNAKÇA}

Acuner, T. ve İlhan, T. (2002). 21. Yüzyılda Yönetim Anlayışı ve Türk Yöneticilerinin Bakış Açısı. 10. Ulusal Yönetim ve Organizasyon Kongresi Bildiri Kitabı. Antalya: Akdeniz Üniversitesi İ.̇̇.B.F. Fakültesi Yayınları.

Akpınar, E. (2006). Kamu Yönetiminde Denetim Olgusu ve Türkiye'de Kamu Yönetiminin Denetlenmesi. Yüksek Lisans Tezi. Isparta: Süleyman Demirel Üniversitesi Sosyal Bilimler Enstitüsü.

Alpar, E. (1999). Yönetim Hukukunun Genel İlkeleri. Türk İdare Dergisi(384), 101-157.

Ardanıç, B. (1982). Modern Yönetim İlkeleri: Karar Verme. Modern Yönetim Semineri Ders Notları. Tưrk - İş Yayınları.

Arıkan, S. (2012). Yönetsel Kademelerde Kadın Yöneticilerin Karşılaştıkları Güçlükler. Polis Bilimleri Dergisi, 1(4), 148-154.

Aytaç, S. (1997). Çalışma Yaşamında Kariyer Yönetimi Planlaması Geliştirilmesi Sorunları.İstanbul: Epsilon Yayınları.

Aytürk, N. (1999). Başarılı Yönetim ve Yöneticilik Teknikleri. Ankara: Yarg1 Basımevi.

Barutçugil, İ. (2002). İş Hayatında Kadın Yönetici. İstanbul: Kariyer Yayınları.

Batı, O. (2013). Türkiye'de Sürdürülebilir Kalkınma ve Yenilenebilir Enerji Kaynakları. Doktora Tezi. İstanbul: Marmara Üniversitesi Sosyal Bilimler Enstitüsü.

Büyüköztürk, Ş., Kılıç Çakmak, E., Akgün, Ö.E., Karadeniz, Ş. ve Demirel, F. (2014). Bilimsel araştırma yöntemleri (17. Baskı). Ankara: Pegem Yayınları

Creswell, J.W. (2014). Educational Research: Planning, Conducting, And Evaluating Quantitative And Qualitative Research. England: Pearson Education Limited.

DGSPW. (1997). Combined 2nd and 3rd Periodic Country Report of Turkey to CEDAW. Ankara: DGSPW Publications.

Doğan, S. (2001). Vizyona Dayalı Liderlik. İstanbul: Seçil Ofset.

Drucker, P. F. (1974). Yönetici Olmak Ne Demektir. (Çeviren, Sabuncuoğlu, G.) Verimlilik Dergisi, $3(2)$.

Eren, E. (1991). Yönetim Psikolojisi. İstanbul: İ.İ.E. 20. Yıl Yayını. 
Ergun, T. (2004). Kamu Yönetimi Kuram, Siyasal, Uygulama. Ankara: Türkiye ve Orta Doğu Amme idaresi Enstitüsü Yayınları.

Eroğlu, H. T. (2000). Kamu Yönetimi Açısından Yönetime Katılma Biçimleri Ve Uygulamaları. Yüksek Lisans Tezi. Konya: Selçuk Üniversitesi Sosyal Bilimler Enstitüsü.

Eryılmaz, B. (2010). Kamu Yönetimi. Ankara: Okutman Yayıncilık.

Fişek, K. (1975). Yönetim. Ankara: Ankara Üniversitesi Basımevi.

Goodland, R. and Ledec, G. (1987). Neoclassical Economics and Principles of Sustainable Development. Ecological Modelling, 38(1-2), 19-46.

Günel, N. (1995). 2000’li Yılların Eşiğinde Yönetsel Denetim Sistemine Eleştirel Bir Bakış. Türk İdare Dergisi(409), 17-35.

Güzel, P., Çoknaz, D. ve Noordegraaf, M. (2009). Sürdürülebilir Kalkınmanın Çevre Boyutunda Uluslararası Olimpiyat Komitesi (Ioc) Uygulamaları ve Olimpiyat Organizasyonları Kapsaminda İncelenmesi. Spor Bilimleri Dergisi, 20(2), 24-34.

Hitt, M. A., Middlemist, R. D. and Mathis, R. L. (1989). Management Concept and Effective Practice. New York: West Publishing Company.

Johnson, B. and Christensen, L.B. (2004). Educational research: Quantitative, qualitative, and mixed approaches. Boston: Pearson Education, Inc.

Kardam, N. (2005). Turkey's Engagement with Global Women's Human Rights. Burlington: Ashgate Publishing.

Miles M. and Huberman M. (1994). Data management and analysis methods. Thousand Oaks, CA: Sage Publications.

Mill, J. S. (1909). Principles of Political Economy with Some of Their Application to Social Philosophy. Clifton: Augustus M. Kelley.

Mintzberg, H. (1990). The Manager's Jop: Folklore and Fact. Harward Business Review, 49-61.

Neumayer, E. (2004). Sustainability and Well-Being Indicators. WIDER Research Papers.

Şimşek, K. (1998). Kalite Yönetimi. İstanbul: Marmara Üniversitesi Yayınları.

Thomas, J. and Harden, A. (2008). Methods for the thematic synthesis of qualitative research in systematic reviews. BMC Medical Research Methodology, 8(45), 1-10.

Tıraş, H. H. (2012). Sürdürülebilir Kalkınma ve Çevre: Teorik Bir. Kahramanmaraş Sütçü İmam Üniversitesi İktisadi ve İdari Bilimler Fakültesi Dergisi, 2(2), 53-57.

UNDP. (2020). Toplumsal Cinsiyet Eşitliği. 5 3, 2020 tarihinde Sustainable Development Goals: https://www.tr.undp.org/content/turkey/tr/home/sustainable-development-goals/goal-5gender-equality (Erişim Tarihi: 15.04.2020).

WCED. (1987). Ortak Geleceğimiz Raporu (Brundtland Raporu). Geneva: World Commission on Environment and Development.

Yaviloğlu, C. (2002). Kalkınmanın Anlambilimsel Tarihi ve Kavramsal Kökenleri. Cumhuriyet Üniversitesi İktisadi ve İdari Bilimler Dergisi, 3(1), 59-76.

Yıldırım, A. ve Şimşek, H. (2018). Sosyal bilimlerde nitel araştırma yöntemleri. Ankara: Seçkin Yayıncilik. 